\title{
Perception of Vendors on Informal Lending
}

\section{Institutions}

\section{Kim Edward S. Santos}

Nueva Ecija University of Science and Technology, Philippines

kimnyte@gmail.com

\begin{abstract}
Informal lending is one of the Philippines ' most common sources of funding for households. The study described the perception of vendors towards informal lending in terms of cost, discretion, patience, humanity or sympathy, and reliability. Survey questionnaire was used in the study. The researcher used likert-scale type questionnaire and analyzed it through statistical data treatment such as mean and weighted mean. The findings of the study are as follows: in terms of cost, informal lending adds investment to business; in terms of discretion, informal lending greatly helps the business; in terms of patience, payment usually is given on the agreed date; in terms of sympathy or humanity, apology seems to be effective in not meeting the agreed date; and in terms of reliability, the ease of access to informal lending.
\end{abstract}

Keywords - Informal Lending, Perception, Cost, Patience, Sympathy or Humanity, Discretion, Business, Reliability.

\section{INTRODUCTION}

Informal lending is one of the Philippines ' most common sources of funding for households. In relation, Fuwa et al. (2015) stated that formal financial institutions are largely underdeveloped within developing economies and, as a result, informal lending serves as a significant medium for credit access.Mansuri (2007) further stated that informal lenders with market or capital exposure frequently find it attractive to assign loan provision to downstream lenders with a knowledge or compliance advantage when dealing with individual borrowers.

Zapata (2006) concluded that less trained, married and/or large-scale households are more likely to borrow from informal lenders. Ferrer (2017) enumerated that certain causes included diminished spouses ' ability to earn family income, poor home wealth and significant mortgage debt, inadequate ability to manage money and financial planning, and high incidence of illicit use of credit.

Dula and Grego (2017) concluded that although the characteristic of their company is informal, the supply of goods and services on the market and the local economy complements consumer activities.It is also important to understand as concluded by Floro (2017) the personal relationship between lenders and borrowers because it also has an influence on other markets, in addition to its effect on the credit transaction. Further, Römer (2017) found that results indicate that treatment group loan borrowers reported lower income, an impact more pronounced in the lowest percentile of income.

In Philippine rice-growing towns, rice merchants and farmer borrowers dominate the informal credit market as stated by Nagarajan et al. (1995).Thus, Briones (2007) concluded that informal lending reflects that borrowing responses should be a major concern in the implementation of finance cost recovery policies.

\section{CONCEPTUAL FRAMEWORK}

This research will be based on the study of Catherine Cross, Community Service Training Programme, University of Natal entitled on "Decision factors involved from a clear pattern. It is mentioned that community seems to evaluate potential lenders on five criteria which is cost, discretion, patience, sympathy or humanity, and reliability." These factors will be the consideration to this study.

This research will help lending institution especially to the vendors of Cabanatuan City to determine the proper comprehension of informal lending and the problems to be encountered in solving using the factors. In this study they will know the advantages of borrowing in lending institution, and how it helps them. 


\section{OBJECTIVE OF THE STUDY}

The study describedthe perception of vendors on informal lending institutions be described in terms of: cost, discretion, patience, sympathy or humanity, and reliability.

\section{METHODOLOGY}

The study used descriptive method as it describes the present condition. The main objective of the study is to explore the causes of particular phenomenon. It further concern with the condition or relationship that exists; practices that prevail; and beliefs and processes that are going on; effects that being felt or trends that are developing. (Cohen, Manion, Morrison, 2002)

The researcher used likert-scale type questionnaire (Vagias, 2006) and analyzed it through statistical data treatment such as mean and weighted mean.

\section{RESULTS}

Table 1 showed that in terms of cost, the statement, "Informal lending has a great impact on my business because it adds to my investment" has the highest weighted mean with 3.65 and interpreted as "Strongly Agree."

Table 1. Perception about Cost

\begin{tabular}{|l|l|l|}
\hline \multicolumn{1}{|c|}{ STATEMENT } & WM & VI \\
\hline $\begin{array}{l}\text { Informal lending has a great impact on } \\
\text { my business because it adds to my } \\
\text { investment. }\end{array}$ & 3.65 & $\begin{array}{l}\text { Strongly } \\
\text { Agree }\end{array}$ \\
\hline $\begin{array}{l}\text { I have enough business income avail } \\
\text { informal lending. }\end{array}$ & 3.31 & $\begin{array}{l}\text { Strongly } \\
\text { Agree }\end{array}$ \\
\hline $\begin{array}{l}\text { I agree with the borrower's interest } \\
\text { ratein informal lending because it's } \\
\text { reasonable in terms of time length. }\end{array}$ & 3.26 & $\begin{array}{l}\text { Strongly } \\
\text { Agree }\end{array}$ \\
\hline $\begin{array}{l}\text { I am encouraged to borrow money in } \\
\text { informal lending because of my } \\
\text { emergency business needs. }\end{array}$ & 3.46 & $\begin{array}{l}\text { Strongly } \\
\text { Agree }\end{array}$ \\
\hline $\begin{array}{l}\text { I favor that when I did not pay the } \\
\text { debtone of my assets would be taken. }\end{array}$ & 3.31 & $\begin{array}{l}\text { Strongly } \\
\text { Agree }\end{array}$ \\
\hline Average Weighted Mean & $\mathbf{3 . 4 0}$ & $\begin{array}{l}\text { Strongly } \\
\text { Agree }\end{array}$ \\
\hline
\end{tabular}

Table 2 showed that in terms of discretion,the statement, "I borrowed money from informallending becauseit greatly helps my business," which has the highest weighted mean with 3.33 and interpreted as "Agree."
Table 2. Perception about Discretion

\begin{tabular}{|l|l|l|}
\hline ITEMS & WM & VI \\
\hline $\begin{array}{l}\text { It's not hard to pay everyday on my } \\
\text { borrowed money. }\end{array}$ & 2.99 & Agree \\
\hline $\begin{array}{l}\text { I will repay informal lending because } \\
\text { it benefits me greatly. }\end{array}$ & 3.19 & Agree \\
\hline $\begin{array}{l}\text { I borrowed money from informal } \\
\text { lending becauseit greatly helps my } \\
\text { business. }\end{array}$ & 3.33 & $\begin{array}{l}\text { Strongly } \\
\text { Agree }\end{array}$ \\
\hline $\begin{array}{l}\text { Informal lending helps with my } \\
\text { livelihood. }\end{array}$ & 3.03 & Agree \\
\hline $\begin{array}{l}\text { I balance my income and expensesto } \\
\text { allocate payment for my debt. }\end{array}$ & 3.25 & $\begin{array}{l}\text { Strongly } \\
\text { Agree }\end{array}$ \\
\hline Average Weighted Mean & $\mathbf{3 . 1 6}$ & Agree \\
\hline
\end{tabular}

Table 3 showed that in terms of Patience, the statement, "I pay on the agreed date of payment" which has the highest weighted mean with 3.43 and interpreted as "Strongly Agree."

Table 3. Perception about Patience

\begin{tabular}{|l|l|l|}
\hline ITEMS & WM & VI \\
\hline I pay on the agreed date of payment. & 3.43 & $\begin{array}{l}\text { Strongly } \\
\text { Agree }\end{array}$ \\
\hline $\begin{array}{l}\text { I always wait for the collector to arrive } \\
\text { on the date of payment. }\end{array}$ & 3.28 & $\begin{array}{l}\text { Strongly } \\
\text { Agree }\end{array}$ \\
\hline I pay based on our agreement terms. & 3.26 & $\begin{array}{l}\text { Strongly } \\
\text { Agree }\end{array}$ \\
\hline $\begin{array}{l}\text { I pay in advance of our agreed date of } \\
\text { payment. }\end{array}$ & 3.36 & $\begin{array}{l}\text { Strongly } \\
\text { Agree }\end{array}$ \\
\hline Average Weighted Mean & 3.33 & $\begin{array}{l}\text { Strongly } \\
\text { Agree }\end{array}$ \\
\hline
\end{tabular}

Table 4 showed that in terms of Sympathy or Humanity, the statement, "I apologize whenever I cannot pay for our agreed date of payment." which has the highest weighted mean with 3.36 and interpreted as "Strongly Agree."

Table 4. Perception about Sympathy or Humanity

\begin{tabular}{|l|l|l|}
\hline ITEMS & WM & VI \\
\hline $\begin{array}{l}\text { I tell the cause of the delay of } \\
\text { payment to the collector. }\end{array}$ & 3.33 & $\begin{array}{l}\text { Strongly } \\
\text { Agree }\end{array}$ \\
\hline $\begin{array}{l}\text { The collector and I treat each } \\
\text { other well. }\end{array}$ & 3.17 & Agree \\
\hline $\begin{array}{l}\text { Every time I miss paying, I ask } \\
\text { for consideration with the } \\
\text { collector. }\end{array}$ & 3.35 & $\begin{array}{l}\text { Strongly } \\
\text { Agree }\end{array}$ \\
\hline
\end{tabular}




\begin{tabular}{|c|c|c|}
\hline $\begin{array}{l}\text { I apologize whenever I cannot pay } \\
\text { for our agreed date of payment. }\end{array}$ & 3.36 & $\begin{array}{l}\text { Strongly } \\
\text { Agree }\end{array}$ \\
\hline Average Weighted Mean & $\mathbf{3 . 3 0}$ & $\begin{array}{c}\text { Strongly } \\
\text { Agree }\end{array}$ \\
\hline
\end{tabular}

Table 5 showed that in terms of Reliability, the statement, "It is easy to borrow money from informal lending without formal requirements" which has the highest weighted mean with 3.41 and interpreted as "Agreed."

Table 5. Perception about Reliability

\begin{tabular}{|c|c|c|}
\hline \multicolumn{1}{|c|}{ ITEMS } & WM & VI \\
\hline $\begin{array}{l}\text { In times of emergency, Informal } \\
\text { lending is very reliable. }\end{array}$ & 3.34 & $\begin{array}{c}\text { Strongly } \\
\text { Agree }\end{array}$ \\
\hline $\begin{array}{c}\text { Informal lending helps the people } \\
\text { without enough credentials to loan } \\
\text { money. }\end{array}$ & 3.38 & $\begin{array}{c}\text { Strongly } \\
\text { Agree }\end{array}$ \\
\hline $\begin{array}{l}\text { It is easy to borrow money from } \\
\text { informal lending without formal } \\
\text { requirements. }\end{array}$ & 3.41 & $\begin{array}{c}\text { Strongly } \\
\text { Agree }\end{array}$ \\
\hline $\begin{array}{l}\text { In terms of business matters, informal } \\
\text { lending is realiable. }\end{array}$ & 3.19 & Agree \\
\hline Average Weighted Mean & 3.33 & Agree \\
\hline \multicolumn{2}{|c|}{} \\
\hline
\end{tabular}

\section{CONCLUSION AND DISCUSSION}

Generally, the respondents were satisfied with the aim of informal lending institution but they still need to gain more knowledge about this institution. The findings of the study are as follows: in terms of cost, informal lending adds investment to business; in terms of discretion, informal lending greatly helps the business; in terms of patience, payment usually is given on the agreed date; in terms of sympathy or humanity, apology seems to be effective in not meeting the agreed date; and in terms of reliability, the ease of access to informal lending.

\section{REFERENCES}

[1] Briones, R. (2007). Do small farmers borrow less when the lending rate increases? The case of rice farming in the Philippines.

[2] Cohen, L., Manion, L., \& Morrison, K. (2002). Research methods in education. routledge.

[3] Dula, R. M., \&Grego, M. P. (2017). Informal Loan Trap: Bombay 5-6 and its Effect on Micro-Entrepreneurs in Tacloban City, Philippines. IMTFI Final Report.

[4] Ferrer, J. C. (2017). Caught in a Debt Trap? An Analysis of the Financial Well-being of Teachers in the Philippines. The Normal Lights, 11(2).
[5] Floro, S. L. (2019). Informal credit markets and the new institutional economics: The case of Philippine agriculture. Routledge.

[6] Fuwa, N., Kajisa, K., Lucio, E., Piza, S. F., \& Sawada, Y. (2015). Hyperbolic Discounting and an Induced Informal Credit Institution by a New Technology: A Case of Debit Card Pawning in the Philippines.

[7] Nagarajan, G., Meyer, R. L., \&Hushak, L. J. (1995). Segmentation in the informal credit markets: the case of the Philippines. Agricultural Economics: The Journal of the International Association of Agricultural Economists, 12(9682016-75741), 171-181.

[8] Römer, U., Weber, R., Mußhoff, O., \&Turvey, C. G. (2017). Truth and consequences: Bogus pipeline experiment in informal small business lending (No. 1702). Diskussionsbeitrag.

[9] Mansuri, G. (2007). Credit layering in informal financial markets. Journal of Development Economics, 84(2), 715-730.

[10] Vagias, W. M. (2006). Likert-type scale response anchors. clemson international institute for tourism. \& Research Development, Department of Parks, Recreation and Tourism Management, Clemson University.

[11] Zapata, N. (2006). Credit decision and rationing rules: a study of informal lenders in the Philippines. Philippine Management Review, 13, 117-126. 